3. Dane H, Duffy C, Guelbenzu M, Hause B, Fee S, Forster F, et al. Detection of influenza D virus in bovine respiratory disease samples, UK. Transbound Emerg Dis. 2019;66:2184-7. https://doi.org/10.1111/tbed.13273

4. Murakami S, Endoh M, Kobayashi T, Takenaka-Uema A, Chambers JK, Uchida K, et al. Influenza D virus infection in herd of cattle, Japan. Emerg Infect Dis. 2016;22:1517-9. https:// doi.org/10.3201/eid2208.160362

5. Salem E, Cook EAJ, Lbacha HA, Oliva J, Awoume F, Aplogan GL, et al. Serologic evidence for influenza C and D virus among ruminants and camelids, Africa, 1991-2015. Emerg Infect Dis. 2017;23:1556-9. https:/ / doi.org/10.3201/ eid2309.170342

6. Murakami S, Odagiri T, Melaku SK, Bazartseren B, Ishida H, Takenaka-Uema A, et al. Influenza D virus infection in dromedary camels, Ethiopia. Emerg Infect Dis. 2019;25:12246. https://doi.org/10.3201/eid2506.181158

7. Faccini S, De Mattia A, Chiapponi C, Barbieri I, Boniotti MB Rosignoli C, et al. Development and evaluation of a new realtime RT-PCR assay for detection of proposed influenza D virus. J Virol Methods. 2017;243:31-4. https://doi.org/ 10.1016/j.jviromet.2017.01.019

8. Kumar S, Stecher G, Li M, Knyaz C, Tamura K. MEGA X: Molecular evolutionary genetics analysis across computing platforms. Mol Biol Evol. 2018;35:1547-9. https:/ / doi.org/ $10.1093 / \mathrm{molbev} / \mathrm{msy} 096$

9. Collin EA, Sheng Z, Lang Y, Ma W, Hause BM, Li F. Cocirculation of two distinct genetic and antigenic lineages of proposed influenza D virus in cattle. J Virol. 2015;89: 1036-42. https:/ / doi.org/10.1128/JVI.02718-14

10. Odagiri T, Ishida H, Li JY, Endo M, Kobayashi T, Kamiki H, et al. Antigenic heterogeneity among phylogenetic clusters of influenza D viruses. J Vet Med Sci. 2018;80:1241-4. https://doi.org/10.1292/jvms.18-0157

Address for correspondence: Taisuke Horimoto, University of Tokyo, Graduate School of Agricultural and Life Sciences, Department of Veterinary Microbiology, 1-1-1 Yayoi, Bunkyo-ku, Tokyo 113-8657, Japan; email: ahorimo@mail.ecc.u-tokyo.ac.jp

\section{Diagnosis of Syphilitic Bilateral Papillitis Mimicking Papilloedema}

\author{
Alicia Gonzalez-Martinez, Sonia Quintas, \\ Diego Celdrán Vivancos, José Cebrián, \\ José Vivancos
}

Author affiliation: Hospital Universitario de la Princesa, Madrid, Spain

DOI: https://doi.org/10.3201/eid2601.191122
Syphilis produces myriad nonspecific signs and symptoms. For example, optic disk swelling might be seen in patients with syphilis as a result of cranial hypertension (papilloedema), inflammatory optic neuritis with papillitis, or optic perineuritis. We report a case involving differential diagnosis of syphilitic bilateral papillitis mimicking papilloedema.

Syphilis, caused by infection with the bacterium Treponema pallidum, is a sexually transmitted infection for which incidence has been increasing since 2002 , especially among adult men $>55$ years of age who engage in risky sex (1). Syphilis has earned its nickname, the "great masquerader," because it produces myriad nonspecific signs and symptoms that make it difficult to distinguish from certain other diseases. Eye impairment occurs in $\geq 3 \%$ of cases $(2,3)$ and can be the first manifestation (4). Optic nerve involvement, either unilateral or bilateral, in the form of papilloedema, perineuritis, or optic neuritis, is the second most common type of syphilitic ocular impairment (5). Each of these conditions shares findings from fundoscopy testing with unilateral or bilateral optic disk swelling (Table), but the etiology and, therefore, the diagnostic algorithm are different. Semiology and ophthalmological findings are the key to achieving a correct syndromic diagnosis.

We describe the case of a 62-year-old man who was admitted to the neurology department at Hospital Universitario de la Princesa in Madrid, Spain, with a 4-day history of bilateral decreased visual acuity. He was obese, an active smoker, and dyslipidemic. He reported neither ocular pain nor dyschromatopsia suggestive of optic neuritis, nor headache or diplopia usually associated with intracranial hypertension. He had no known history of syphilis. Visual acuity was 20/32 in the right eye and 20/63 in the left. Pupils were equal and reactive to light, with no relative afferent pupillary defect, which is typical of unilateral optic neuritis. Slit lamp examination results were normal, showing no inflamed cells in the anterior chambers or vitreous. Neurologic examination was normal. Opening pressure of the cerebrospinal fluid (CSF) on lumbar puncture was $27 \mathrm{~cm} \mathrm{H}_{2} \mathrm{O}$, above the reference range of $5-20 \mathrm{~cm} \mathrm{H}_{2} \mathrm{O}$. The CSF white cell count was 0 , with normal glucose and protein levels. A fundus examination revealed bilateral optic disk swelling and peripapillary retinitis; visual field testing revealed bilateral central scotoma and an enlarged blind spot (Appendix, https:/ / wwwnc.cdc. gov/EID/article/26/1/19-1122-App1.pdf).

Doctors initiated acetazolamide for suspected idiopathic intracranial hypertension (IIH), but 
Table. Differential diagnosis of syphilitic optic disk swelling*

\begin{tabular}{|c|c|c|c|c|c|c|c|}
\hline $\begin{array}{l}\text { Differential } \\
\text { diagnosis }\end{array}$ & $\begin{array}{c}\text { Clinical } \\
\text { presentation }\end{array}$ & $\begin{array}{l}\text { Visual } \\
\text { acuity }\end{array}$ & Visual fields & $\begin{array}{c}\text { Optic disk } \\
\text { appearance }\end{array}$ & $\begin{array}{l}\text { Other ocular } \\
\text { abnormalities }\end{array}$ & $\begin{array}{c}\text { Lumbar CSF } \\
\text { opening } \\
\text { pressure } \\
\end{array}$ & Orbital MRI \\
\hline Papilloedema & $\begin{array}{c}\text { Headache, } \\
\text { nausea, tinnitus, } \\
\text { diplopia, neck } \\
\text { stiffness, } \\
\text { photophobia }\end{array}$ & $\begin{array}{l}\text { Normal to } \\
\text { slow } \\
\text { reduction } \\
\text { (months) }\end{array}$ & $\begin{array}{c}\text { Enlarged blind } \\
\text { spot }\end{array}$ & Swollen & $\begin{array}{c}\text { Flame } \\
\text { hemorrhages }\end{array}$ & High & $\begin{array}{l}\text { Normal/flattening } \\
\text { of the posterior } \\
\text { sclera, dilation of } \\
\text { the ONS, and } \\
\text { protrusion of the } \\
\text { optic disk head }\end{array}$ \\
\hline Perineuritis & Asymptomatic & Normal & $\begin{array}{c}\text { Enlarged blind } \\
\text { spot, } \\
\text { constricted } \\
\text { peripheral } \\
\text { visual field }\end{array}$ & $\begin{array}{l}\text { Slightly } \\
\text { swollen }\end{array}$ & None & Normal & $\begin{array}{l}\text { ONS and orbital } \\
\text { fat expansion and } \\
\text { enhancement }\end{array}$ \\
\hline $\begin{array}{l}\text { Anterior optic } \\
\text { neuritis } \\
\text { (papillitis) }\end{array}$ & $\begin{array}{c}\text { Ocular pain, } \\
\text { dyschromatopsia }\end{array}$ & $\begin{array}{l}\text { Reduced } \\
\text { (hours- } \\
\text { days) }\end{array}$ & $\begin{array}{l}\text { Enlarged blind } \\
\text { spot, central } \\
\text { scotomas, and } \\
\text { other field } \\
\text { abnormalities }\end{array}$ & Swollen & $\begin{array}{l}\text { None/cellular } \\
\text { activity in the } \\
\text { posterior } \\
\text { vitreous, patchy } \\
\text { diffuse retinitis }\end{array}$ & Normal & $\begin{array}{l}\text { Optic nerve } \\
\text { gadolinium } \\
\text { enhancement }\end{array}$ \\
\hline
\end{tabular}

${ }^{*} \mathrm{CSF}$ cerebrospinal fluid; MRI, magnetic resonance imaging; ONS optic nerve sheath.

†Normal lumbar CSF pressure: $<25 \mathrm{~cm} \mathrm{H}_{2} \mathrm{O},<28 \mathrm{~cm} \mathrm{H}_{2} \mathrm{O}$ in obese patients.

visual acuity decreased to $20 / 40$ in the right eye and 20/200 in the left. The rapid decrease in visual acuity and the lack of response to acetazolamide suggested optic nerve involvement, which seemed atypical for IIH in the absence of other cranial nerve impairment (being the sixth cranial nerve, which is most likely to be affected IIH in the first place).

A cerebral magnetic resonance imaging scan with gadolinium did not reveal any structural lesion or indirect findings of IIH. For this reason, the diagnostic study was expanded. Optical coherence tomography of the nerve fiber layer showed an increase in average thickness in both eyes, reflecting optic nerve edema. Results from laboratory tests for complete blood count, urea, electrolytes, enzymes, hormones, antinuclear antibodies, and protein electrophoresis were within normal ranges. Test results were negative for HIV. A treponemal test reacted negatively to a nontreponemal Venereal Disease Research Laboratory (VDRL) test in serum, but a VDRL test in CSF was reactive without dilution. Treatment with intravenous penicillin $\mathrm{G}\left(4 \times 10^{6} \mathrm{U}\right.$, every $8 \mathrm{~h}$ for $14 \mathrm{~d}$ ) was initiated. Fundoscopy results were normal, visual acuity remained stable but unimproved $(0 / 40$ in the right eye and 20/200 in the left eye, which was not unexpected), and visual fields remained stable 3 months after penicillin treatment was begun (Appendix). Lumbar puncture at that time revealed normal opening pressure and negative results for VDRL test scores.

Papilloedema refers to optic disk edema caused by increased intracranial pressure. The initial pressure of $27 \mathrm{~cm} \mathrm{H}_{2} \mathrm{O}$ for this patient, despite being high, was lower than the $28 \mathrm{~cm} \mathrm{H}_{2} \mathrm{O}$ in obese patients required to diagnose $\mathrm{IIH}$, according to the latest International
Classification of Headache Disorders standards (6). Syphilitic optic perineuritis is usually asymptomatic (7) because the inflammation is restricted to the optic nerve sheath, rather than the nerve itself (8). Clinical suspicion of that condition arises in the presence of optic disk swelling with normal CSF pressure and visual acuity (9). Optic neuritis, unlike these other conditions, is usually accompanied by rapid visual failure, as seen in this patient. Ocular pain is a common finding but not necessary for diagnosis.

Because the optic nerve and retina are considered extensions of the central nervous system, patients with ocular syphilis should undergo lumbar puncture and CSF analysis to confirm neurologic involvement. Diagnosing neurosyphilis relies on a combination of symptoms and signs verified by laboratory studies of blood and CSF (10), ocular symptoms due to bilateral papillitis, and positive treponemal test in serum and VDRL in CSF. This patient met these criteria.

Our findings underline that IIH can only be diagnosed through systematic exclusion of alternative diagnoses and the diagnosis cannot be reached by fundoscopy findings alone. Clinical findings are key points for differentiating papilloedema and ocular perineuritis from papillitis. A complete diagnostic work up is required to rule out all other etiologic causes of optic neuropathy and, if the diagnosis of ocular syphilis is reached, a lumbar puncture should be performed to rule out neurosyphilis.

\section{About the Author}

Dr. Gonzalez-Martinez is currently completing her residency in neurology at Hospital Universitario de la Princesa, Madrid. She has previously worked at 
Karolinska Institutet and Massachusetts General Hospital (Harvard Medical School). Her areas of interest are clinical neurology and translational research.

\section{References}

1. STI Study Group. Syphilis and gonorrhoea diagnoses in a network of STI centres, 2005-2008. Madrid:National Centre of Epidemiology; 2010.

2. Doris JP, Saha K, Jones NP, Sukthankar A. Ocular syphilis: the new epidemic. Eye (Lond). 2006;20:703-5. https://doi.org/10.1038/sj.eye.6701954

3. Apinyawasisuk S, Poonyathalang A, Preechawat P, Vanikieti K. Syphilitic optic neuropathy: re-emerging cases over a 2-year period. Neuroophthalmology. 2016;40:69-73. https://doi.org/10.3109/01658107.2015.1134586

4. Bandettini di Poggio M, Primavera A, Capello E, Bandini F, Mazzarello G, Viscoli C, et al. A case of secondary syphilis presenting as optic neuritis. Neurol Sci. 2010;31:3657. https:/ / doi.org/10.1007/s10072-010-0222-8

5. Lapere S, Mustak H, Steffen J. Clinical manifestations and cerebrospinal fluid status in ocular syphilis. Ocul Immunol Inflamm. 2019;27:126-30. https:// doi.org/10.1080/ 09273948.2018.1521436

6. Headache Classification Committee of the International Headache Society (IHS). The International Classification of Headache Disorders, 3rd edition. Cephalalgia. 2018;38:1211. https://doi.org/10.1177/0333102417738202

7. O'Connell K, Marnane M, McGuigan C. Bilateral ocular perineuritis as the presenting feature of acute syphilis infection. J Neurol. 2012;259:191-2. https://doi.org/10.1007/ s00415-011-6148-0

8. Meehan K, Rodman J. Ocular perineuritis secondary to neurosyphilis. Optom Vis Sci. 2010;87:E790-6. https://doi.org/10.1097/OPX.0b013e3181f361b0

9. Gartaganis S, Georgiou S, Monastirli A, Katsimpris J, Pasmatzi E, Tsambaos D. Asymptomatic bilateral optic perineuritis in secondary syphilis. Acta Derm Venereol. 2000;80:75-6. https://doi. org/10.1080/000155500750012720

10. Workowski KA, Berman SM. CDC sexually transmitted diseases treatment guidelines. Clin Infect Dis. 2002;35(Suppl 2):S135-7. https://doi.org/10.1086/342100

Address for correspondence: Sonia Quintas, Hospital Universitario de la Princesa, Calle Diego de León, 62, Secretaría de Neurología, 28006 Madrid, Spain; email: sonia.qg@gmail.com

\section{Influenza A Virus Infections in Dromedary Camels, Nigeria and Ethiopia, 2015-2017}

\author{
Daniel K.W. Chu, ${ }^{1}$ Ranawaka A.P.M. Perera, ${ }^{1}$ \\ Abraham Ali, ${ }^{1}$ Jamiu O. Oladipo, Gezahegne Mamo, \\ Ray T.Y. So, Ziqi Zhou, Yen Yeen Chor, \\ Chak Kai Chan, Desalegn Belay, Adamu Tayachew, \\ Mesfin Mengesha, Feyesa Regassa, Nga Ting Lam, \\ Leo L.M. Poon, Malik Peiris
}

Author affiliations: The University of Hong Kong, Hong Kong, China (D.K.W. Chu, R.A.P.M. Perera, J.O. Oladipo, R.T.Y. So, Z. Zhou, Y.Y. Chor, C.K. Chan, N.T. Lam, L.L.M. Poon, M. Peiris); Ethiopian Public Health Institute, Addis Ababa, Ethiopia (A. Ali, D. Belay, A. Tayachew, M. Mengesha, F. Regassa); Addis Ababa University, Bishoftu, Ethiopia (G. Mamo)

DOI: https://doi.org/10.3201/eid2601.191165

We examined nasal swabs and serum samples acquired from dromedary camels in Nigeria and Ethiopia during 2015-2017 for evidence of influenza virus infection. We detected antibodies against influenza $A(H 1 N 1)$ and $A(H 3 N 2)$ viruses and isolated an influenza $A(H 1 N 1)$ pdm09-like virus from a camel in Nigeria. Influenza surveillance in dromedary camels is needed.

$\Delta$ quatic wild birds are the natural reservoir of Ainfluenza A virus, which comprises 16 hemagglutinin and 9 neuraminidase subtypes. Influenza A virus subtypes $\mathrm{H} 1 \mathrm{~N} 1, \mathrm{H} 2 \mathrm{~N} 2$, and $\mathrm{H} 3 \mathrm{~N} 2$ have caused pandemics in humans, and subtypes H1N1 and H3N2 circulate in humans as seasonal influenza. Pandemic influenza arises when an animal influenza virus evolves through the reassortment of animal and human virus gene segments (antigenic shift) to sustainably transmit in humans. Avian and swine influenza viruses have caused zoonotic infections, some resulting in fatal disease. Thus, influenza virus surveillance in animals is needed for pandemic preparedness (1).

Dromedary camel populations, estimated to be 30 million globally, can be found in parts of Africa, the Middle East, and Central Asia, often in close proximity to humans. An equine influenza $\mathrm{A}(\mathrm{H} 3 \mathrm{~N} 8)$ virus (2) and human influenza A/USSR/90/77(H1N1)-like viruses (which were associated with fatal disease in 1980-1983) (3) have been isolated from Bactrian camels in Mongolia. However, little is known of influenza A virus infections in dromedary populations.

${ }^{1}$ These authors contributed equally to this article. 